\title{
Effect of Irrigation System, Tillage System, and Seeding Rates on Wheat (Triticum aestivum L.) Growth, Grain Yield and Its Water Consumption and Efficiency
}

\author{
Alaa M. Akol1, 2, Nadine Nassif ${ }^{3}$, Khudhair Abbas Jaddoa4, Haider M. Zwain'1, \\ Kareem Radhi', Nadhir Al-Ansari ${ }^{*}$ * \\ ${ }^{1}$ Ecole Doctorale en Sciences et Technologie, Lebanese University, Beirut, Lebanon \\ ${ }^{2}$ College of Water Resources Engineering, Al-Qasim Green University, Al-Qasim Province, Babylon, Iraq \\ ${ }^{3}$ Faculty of Agronomy and Veterinary Sciences, Environment and Natural Resources department, Lebanese University, Dekwaneh, \\ Beirut, Lebanon \\ ${ }^{4}$ College of Agricultural Engineering Sciences, Baghdad University, Baghdad, Iraq \\ ${ }^{5}$ Department of Civil, Environmental and Natural Resources Engineering, University of Technology, Lulea, Sweden \\ Email: alaamahdi@wrec.uoqasim.edu.iq, haider.zwain@wrec.uoqasim.edu.iq, nadinenassif3@hotmail.com, \\ khdhayerjaddoa@yahoo.com, ^nadhir.alansari@ltu.se
}

How to cite this paper: Akol, A.M., Nassif, N., Jaddoa, K.A., Zwain, H.M., Radhi, K. and Al-Ansari, N. (2021) Effect of Irrigation System, Tillage System, and Seeding Rates on Wheat (Triticum aestivum L.) Growth, Grain Yield and Its Water Consumption and Efficiency. Engineering, 13, 574-594. https://doi.org/10.4236/eng.2021.1311042

Received: September 12, 2021 Accepted: November 26, 2021 Published: November 29, 2021

Copyright $\odot 2021$ by author(s) and Scientific Research Publishing Inc. This work is licensed under the Creative Commons Attribution International License (CC BY 4.0).

http://creativecommons.org/licenses/by/4.0/ (c) (i) Open Access

\begin{abstract}
A field trial was conducted at a private farm in AL-Hashimiya district Babylon Governorate-the republic of Iraq during the 2016-2017 and 2017-2018 growing seasons. This study was conducted using two irrigation methods, sprinkler and surface irrigation, for each of them had three Tillage methods (zero-tillage, medium-tillage, deep-tillage) and each tillage system had four seeding rate of wheat yield $(120,180,240,300) \mathrm{kg} \cdot \mathrm{ha}^{-1}$. Results indicated that the consumptive water use was 557.5 and $535.9 \mathrm{~mm}$ for surface irrigation and 460.9 and $442.6 \mathrm{~mm}$ for sprinkler irrigation in the 2016-2017 and 2017-2018 growing seasons. Sprinkler irrigation significantly increased the flag leaf area with no significant effect on plant height. However, the minimum tillage and seeding rate $\left(240 \mathrm{~kg} \cdot \mathrm{ha}^{-1}\right)$ significantly increased the plant height and flag leaf area in both growing seasons. For the grain yield, the sprinkler irrigation, minimum tillage, and seeding rate $\left(240 \mathrm{~kg} \cdot \mathrm{ha}^{-1}\right)$ also increased the plant height and flag leaf area by $13 \%, 10, \% 11 \%, 11 \%, 12 \%$, and $14 \%$ in both growing seasons, respectively, through an increased number of spikes $/ \mathrm{m}^{2}$, the number of grain spike-1, and 1000-grain weight in both growing seasons, respectively. Interestingly the grain yield was increased by $33 \%$ and $32 \%$ in both growing seasons under the effects of these three factors altogether, respectively. It can be concluded that these factors act synergistically, resulting in a significant
\end{abstract}


improvement in the wheat grain-yield of, less consumptive water use, and high water use efficiency.

\section{Keywords}

Irrigation, Tillage system, Seeding rates, Wheat (Triticum Aestivum L.), Grain yield, Water Consumption

\section{Introduction}

A major challenge in crop production is to achieve the goal of increasing both yield and resource use efficiency. Irrigation water is a scarce and expensive resource constraining wheat production in semi-arid and arid regions. Globally, agriculture uses almost 70\% of all freshwater withdrawals for irrigation [1]. In Iraq, water has become a limiting factor for growing most crops due to the shortage of water in both Tigris and Euphrates rivers and scarcity of rains, especially in the northern parts of Iraq where almost two-thirds of the wheat crop are grown in the so-called rainfed areas. Iraq is facing a serious water shortage problem for the first time in its long history. Wheat is a major cereal crop widely grown in Iraq that is in the first rank as the highest acreage is specified to the wheat each year. In the 2016-2017 growing season, the total cultivated area under wheat, total production, and productivity in Iraq were 1,054,000 ha, 2,974,000 t, and $1822 \mathrm{~kg} \cdot \mathrm{ha}^{-1}$, respectively (Ministry of planning, directorate of agriculture statistics, 2017). This reflects the importance of this vital crop as a source of proteins and calories locally and globally, with an annual production of about 730 million tonnes globally [2].

When water is not easily accessible in the required amounts for plants, it will adversely affect growth and plant development in terms of anatomy, morphology, physiology, and biochemistry, leading to a reduction in plant leaf size and yield [3] [4] [5] [6]. Therefore, research centers and universities should pay more attention and interest in dealing with such problems by adopting suitable approaches and agronomic practices, including using sprinkler irrigation, tillage system, and seeding rates to develop drought-resistant crops to water shortage and using water efficiently. Sprinkler irrigation is one of the methods used to supply plants with the required amount of water efficiency and reduce water loss [7]. It is widely applied globally due to its advantages [8]. However, in Iraq, it is still used at a limited level. The process of preparing the soil for growing crops is of great importance, particularly tillage, which makes a significant change in the soil structure [9]. Tillage systems affect soil properties such as temperature, moisture, bulk density, particle aggregation, organic matter content, and plant properties, such as root density. Improving soil properties is an essential part of the sustainable intensification of crop production systems [10].

There are three tillage practices, conventional tillage, minimum tillage, and 
zero tillage, each with its advantages and disadvantages. No-tillage or minimum tillage is an important, valuable strategy for improving grain yield in arid regions [11] [12] [13]. Furthermore, the minimum tillage-based conservation agriculture is a crucial strategy for crop intensification, especially when combined with crop residue retention, which can substantially improve soil properties [14]. The seeding rate $(S)$ is one of the essential agronomic practices relevant to the irrigation and tillage system, as it is the crucial factor for plants in their efficient exploitation of available resources (water, air, radiation, fertilizer, and anything affecting plant growth) [15]. Therefore, the present study aims to investigate the effect of three interrelated factors: the irrigation system (sprinkler irrigation and surface irrigation), tillage system (zero tillage, minimum tillage, and deep tillage), and seeding rates $\left(120,180,240\right.$, and $300 \mathrm{~kg} \cdot \mathrm{ha}^{-1}$ ) on wheat (Triticum aestivum L.) growth, grain yield and its water consumption and efficiency.

\section{Materials and Methods}

\subsection{Study Area}

A field experiments were conducted at Al-Hashimya District, Babylon Province, Iraq (Figure 1). The landform is a plain area about $25.2 \mathrm{~m}$ above sea level, characterized by alluvial soils and classified under the super group "Typic Torrifluvent". Among the climate characteristics of the region, some are a subtropical climate with an average air temperature of $25.6 \mathrm{Co}$, an average annual rainfall of about $135 \mathrm{~mm}$, evaporation above $2122 \mathrm{~mm}$, and an average wind speed of 3.8 $\mathrm{m} \cdot \mathrm{sec}^{-1}$ with a relative humidity of $38 \%$. Figure 2 shows climate data in at $\mathrm{Al}$ Hashimya District (Iraqi Ministry of Agriculture, 2017-2018). The texture class is clay loam and soil $\mathrm{pH}$ of (7.31) with a medium-high land type, as shown in Table 1.

\subsection{Soil Preparation}

Three tillage methods were used to prepare the soil by plowing it, including zero

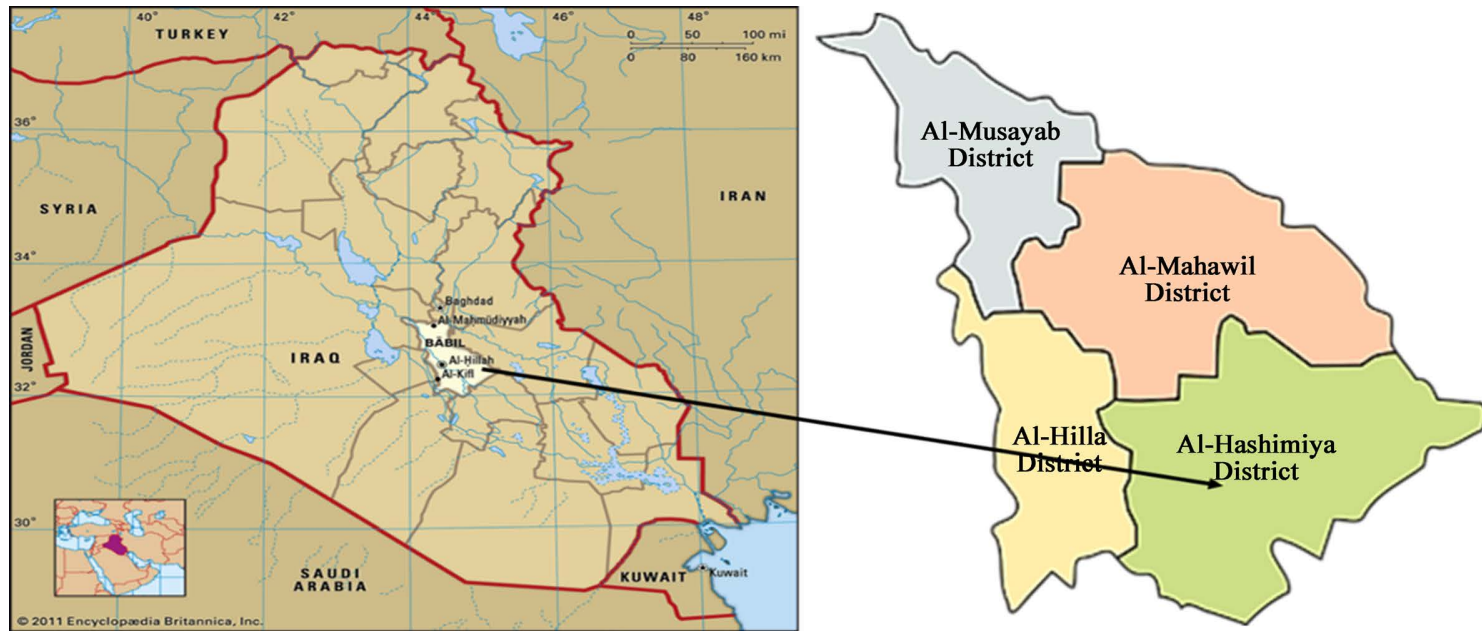

Figure 1. The geographical location of study area. 


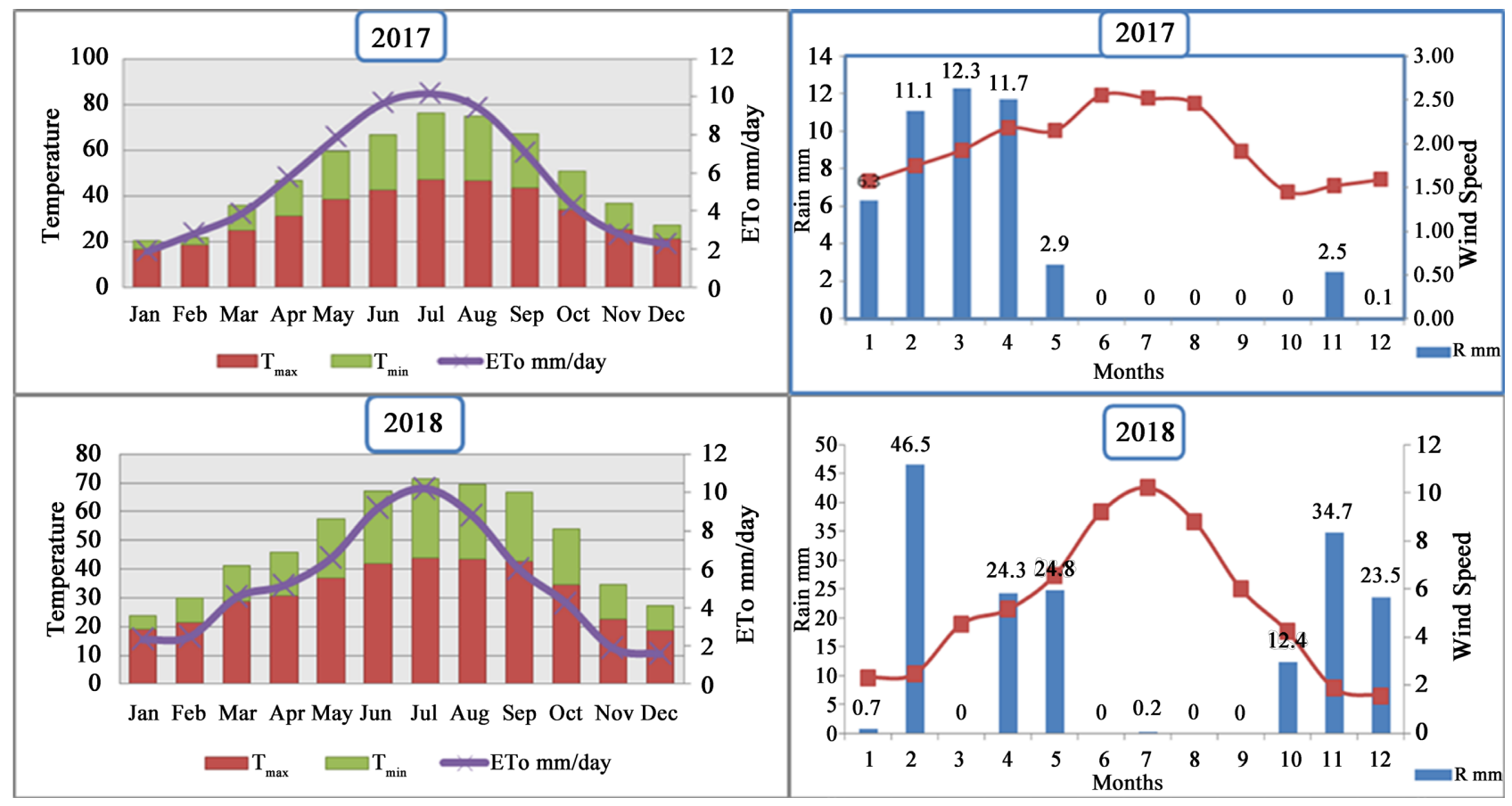

Figure 2. Climate data for 2017 and 2018 seasons.

Table 1. Selected physical and chemical properties for experimental soil.

\begin{tabular}{|c|c|}
\hline Characteristics & Value \\
\hline $\mathrm{Ec}\left(\mathrm{ds} \cdot \mathrm{m}^{-1}\right)$ & 2.34 \\
\hline $\mathrm{PH}$ & 7.31 \\
\hline Sand $\left(\mathrm{g} \cdot \mathrm{kg}^{-1}\right)$ & 160 \\
\hline Silt $\left(g \cdot \mathrm{kg}^{-1}\right)$ & 490 \\
\hline Clay $\left(\mathrm{g} \cdot \mathrm{kg}^{-1}\right)$ & 350 \\
\hline Textural Class & Silty Clay Loam \\
\hline $\mathrm{Ca}\left(\mathrm{meq} \cdot \mathrm{L}^{-1}\right)$ & 12.41 \\
\hline $\operatorname{Mg}\left(\mathrm{meq} \cdot \mathrm{L}^{-1}\right)$ & 5.60 \\
\hline $\mathrm{Na}\left(\mathrm{meq} \cdot \mathrm{L}^{-1}\right)$ & 3.86 \\
\hline $\mathrm{K}\left(\mathrm{meq} \cdot \mathrm{L}^{-1}\right)$ & 1.55 \\
\hline $\mathrm{HCO}_{3}^{-} \quad\left(\mathrm{meq} \cdot \mathrm{L}^{-1}\right)$ & 2.89 \\
\hline $\mathrm{Cl}^{-}\left(\mathrm{meq} \cdot \mathrm{L}^{-1}\right)$ & 14.15 \\
\hline $\mathrm{SO}_{4}^{2-} \quad\left(\mathrm{meq} \cdot \mathrm{L}^{-1}\right)$ & 7.87 \\
\hline Organic Matter (\%) & 1.50 \\
\hline Bulk Density $\left(\mathrm{g} \cdot \mathrm{cm}^{-3}\right)$ & 1.38 \\
\hline Particle Density $\left(\mathrm{g} \cdot \mathrm{cm}^{-3}\right)$ & 2.65 \\
\hline Hydraulic Conductivity $\left(\mathrm{cm} \cdot \mathrm{h}^{-1}\right)$ & 0.72 \\
\hline
\end{tabular}


tillage, minimum tillage, and deep tillage, with a board plow bottom not exceeding $15 \mathrm{~cm}$ depth. The deep plowing was conducted to a depth of $30 \mathrm{~cm}$ using a chisel plow [13]. After that, the soil was leveled and divided into plots, each with a dimension of $4 \times 5 \mathrm{~m}^{2}$. Then the sprinkler irrigation system was installed by laying the main pipes with a spacing of $10 \mathrm{~m}$. The distance between the sprinklers was $10 \mathrm{~m}$. As for the surface irrigation system, plastic tubes with a diameter of 2 inches were used, and a meter was attached to measure the amount of irrigation water to be added to each plot. A soil separation distance of $3 \mathrm{~m}$ was left between the two systems to prevent the impact of the sprinkler irrigation system on the surface irrigation system [16].

\subsection{Experimental Procedure}

The experiment layout was designed using a split-split plot design with three replicates (R1, R2, and R3). As distributed in Figure 3, irrigation methods were surface irrigation (I1) and sprinkler irrigation (I2), tillage methods were zero tillage (T0), minimum tillage (T1) and deep tillage (T2), and seeding rate were 120 , 180,240 and $300 \mathrm{~kg} \cdot \mathrm{ha}^{-1}$. The data were statistically analyzed by Least Significant Differences method (LSD) at confidence level of 95\% $(\mathrm{P}<0.05)$ using GenStat program [17].

\subsection{Agronomic Practices}

Seeds of wheat were sown on $1^{\text {st }}$ December in the 2016 and 2017 growing seasons, respectively. Seeds were planted in rows with a spacing of $20 \mathrm{~cm}$. The experimental units were fertilized according to the agricultural extension recommendations of the experiment region by adding $100 \mathrm{~kg} \cdot \mathrm{ha}^{-1} \mathrm{P}_{2} \mathrm{O}_{5} 46 \%$ once at the soil preparation, and $200 \mathrm{~kg} \cdot \mathrm{ha}^{-1}$ nitrogen (urea $46 \%$ ) as top dressing three times at the beginning of tillering, stem elongation, and booting stages [18]. The

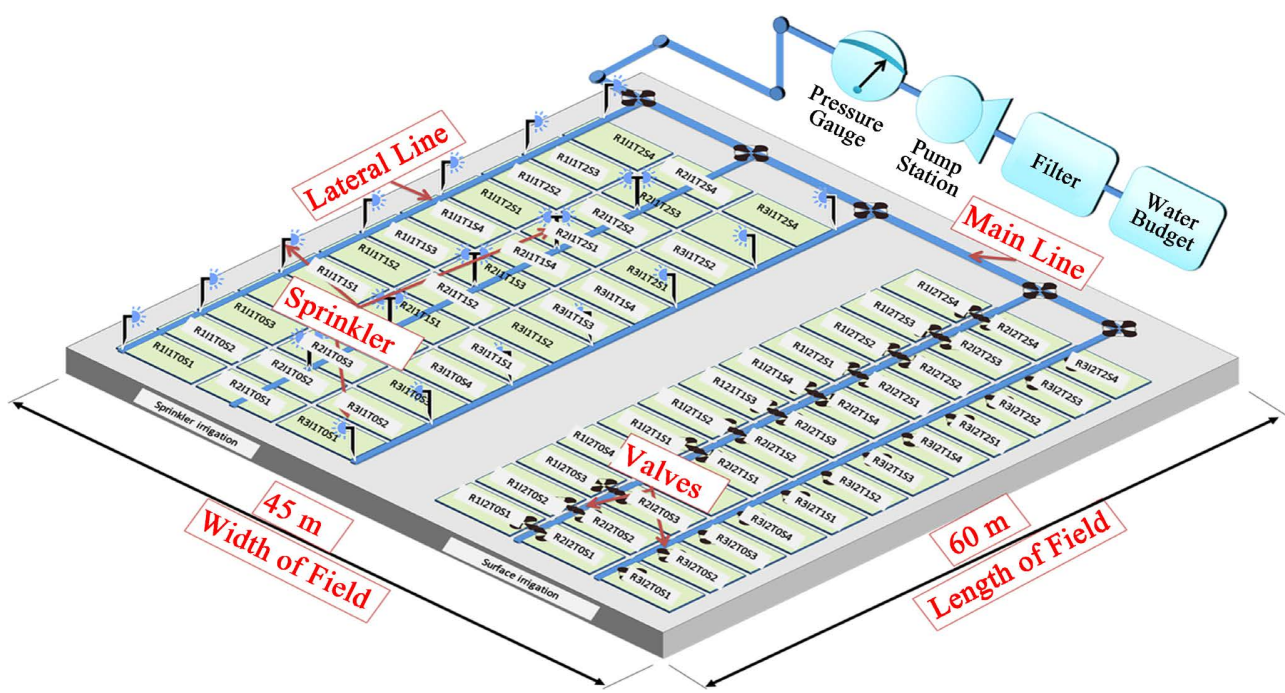

Figure 3. Experimental design layout $(\mathrm{R} 1=$ replicate $1, \mathrm{R} 2=$ replicate $2, \mathrm{R} 3=$ replicate 3 ; $\mathrm{I} 1=$ sprinkler irrigation, $\mathrm{I} 2=$ surface irrigation; $\mathrm{T} 0=$ zero tillage, $\mathrm{T} 1=$ minimum tillage, $\mathrm{T} 2=$ deep tillage (T2); S1 = $120 \mathrm{~kg} \cdot \mathrm{ha}^{-1}$, S2 = $180 \mathrm{~kg} \cdot \mathrm{ha}^{-1}, \mathrm{~S} 3=240 \mathrm{~kg} \cdot \mathrm{ha}^{-1}, \mathrm{~S} 4=300 \mathrm{~kg} \cdot \mathrm{ha}^{-1}$ ). 
harvest was performed on 10/5/2017 and 8/5/2018.

\subsection{Irrigation Water Supply}

The irrigation process was performed after depletion of $50 \%$ of the available water. The amount of supplied water was measured each time, depending on the soil moisture content calculation before irrigation. The irrigation was carried out based on moisture depletion of the $0-10 \mathrm{~cm}$ layer from the sowing to the end of the vegetative growth phase. The irrigation depth was increased up to $10-20 \mathrm{~cm}$ for the flowering stage based on moisture depletion and $20-30 \mathrm{~cm}$ to the end of physiological maturity to reach moisture content near field capacity [8]. Soil field capacity and permanent wilting point were measured using a pressure plate apparatus, while available water content was calculated using Equation (1) [19].

$$
\mathrm{D}=[(\mathrm{FC}-\mathrm{PWP}) \times \mathrm{BD} \times \mathrm{D}] / 100
$$

where, $\mathrm{D}=$ Available water depth (\%), FC $=$ Field capacity, $\mathrm{PWP}=$ Permanent wilting point, $\mathrm{BD}=$ Bulk density $\left(\mathrm{Mg} / \mathrm{m}^{3}\right), \mathrm{D}=$ Soil depth $(\mathrm{cm})$

The water balance Equation (2) was used as a direct method for calculating the wheat crops actual water consumption [20].

$$
(\mathrm{I}+\mathrm{P}+\mathrm{C})-(\mathrm{ETa}+\mathrm{D}+\mathrm{R})=\Delta \mathrm{S}
$$

where:

$\Delta$ S: Change in storage soil moisture, I: Water applied by irrigation, P: Rainfall, C: Capillary rise.

ETa: Crop evapotranspiration $\left[\mathrm{mm} \cdot \mathrm{d}^{-1}\right]$, D: Deep soil drainage, and R: Surface runoff.

When $\Delta \mathrm{S}=$ zero because the soil moisture storage is the same at the beginning and end of the season; $\mathrm{P}=$ zero to block rain by covering, and $\mathrm{D}=$ zero because irrigation is conducted with a drainage limit of $50 \%$ of available water and a certain depth of the soil layer $0-30 \mathrm{~cm}$. Therefore, Equation (4) becomes Equation (3):

$$
\mathrm{ETa}=\mathrm{I}+\mathrm{C} .
$$

\section{Test Water Use Efficiency}

The efficiency of field water use was calculated according to Equation (4) [21].

$$
\text { WUEf }=\mathrm{Y} / \mathrm{WA}
$$

where:

WUEf $=$ Efficient use of field water $\left(\mathrm{kg} \cdot \mathrm{m}^{-3}\right), \mathrm{Y}=$ Grain yield $(\mathrm{kg})$, and $\mathrm{WA}=$ The amount of water added in the irrigation process $\left(\mathrm{m}^{3} \cdot\right.$ Season $\left.^{-1}\right)$.

\subsection{Growth Characteristics}

Plant height was measured from the soil surface up to the awns ends for ten plants randomly chosen from each experimental unit. Flag leaf area $\left(\mathrm{cm}^{2}\right)$ was calculated using Equation (5) [22]. 


$$
\text { Flag leaf area }\left(\mathrm{cm}^{2}\right)=\mathrm{L} \times(\mathrm{Mw})^{0.75}
$$

where:

$\mathrm{L}=$ Flag leaf length $(\mathrm{cm}), \mathrm{Mw}=$ Depth of flag leaf al the middle $(\mathrm{cm})$, and 0.75 $=$ Constant

Grain yield and its components was conducted by an average weight of 1000 grains was randomly taken from the yield from each experimental unit and weighed by a sensitive electronic scale [23]. Grain yield was tested by an area of $1.2 \mathrm{~m}^{2}$ was harvested in each plot (four rows in the middle with $2 \mathrm{~m}$ in length). Grains were separated from the straw, weighed, and transformed to the th $\mathrm{ha}^{-1}$ at $14 \%$ moisture content of grains [24].

\section{Results and Discussion}

\subsection{Growth Characteristics}

\subsubsection{Plant Height}

It is clear from Figure 4 and Figure 5 that the irrigation system had no significant effect on plant height in both growing seasons. However, the tillage system and seeding rate significantly affected this characteristic in both growing seasons. For the tillage system, minimum tillage gave the highest average of plant height (82.29 and 82.25) $\mathrm{cm}$ compared with the lowest average of 74.00 and $74.08 \mathrm{~cm}$ in both growing seasons. Concerning the interaction, all bi and triple interactions were significant in both growing seasons. The highest average of plant height $84.44 \mathrm{~cm}$ was under the sprinkler irrigation I1, and the high seeding rate $240 \mathrm{~kg} \cdot \mathrm{ha}^{-1}(\mathrm{~S} 3)$ compared with the lowest one $72.00 \mathrm{~cm}$ under surface irrigation $\mathrm{I} 2$ and for the lowest seeding rate (S1) in both growing seasons. The same effect of S3 seeding rate was obtained under the minimum tillage $\mathrm{T} 1$, in both

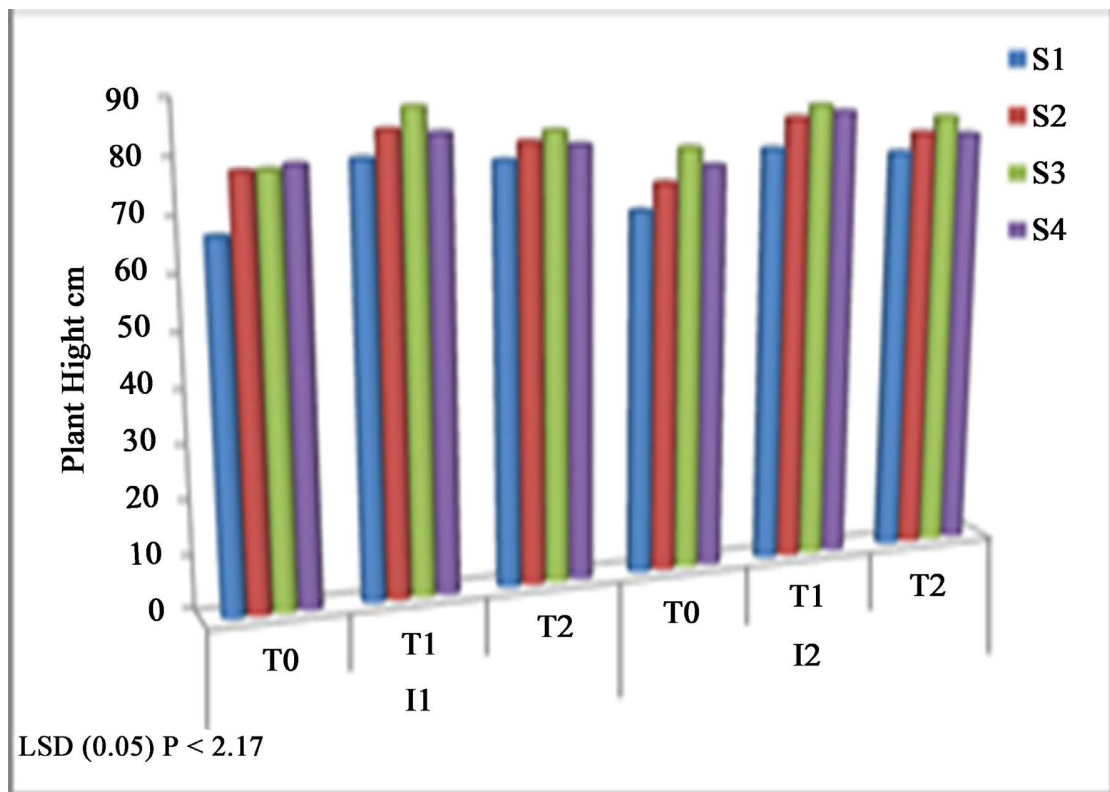

Figure 4. Effect of irrigation system tillage system and seeding rate on plant height $(\mathrm{cm})$ 2016-2017 season. 


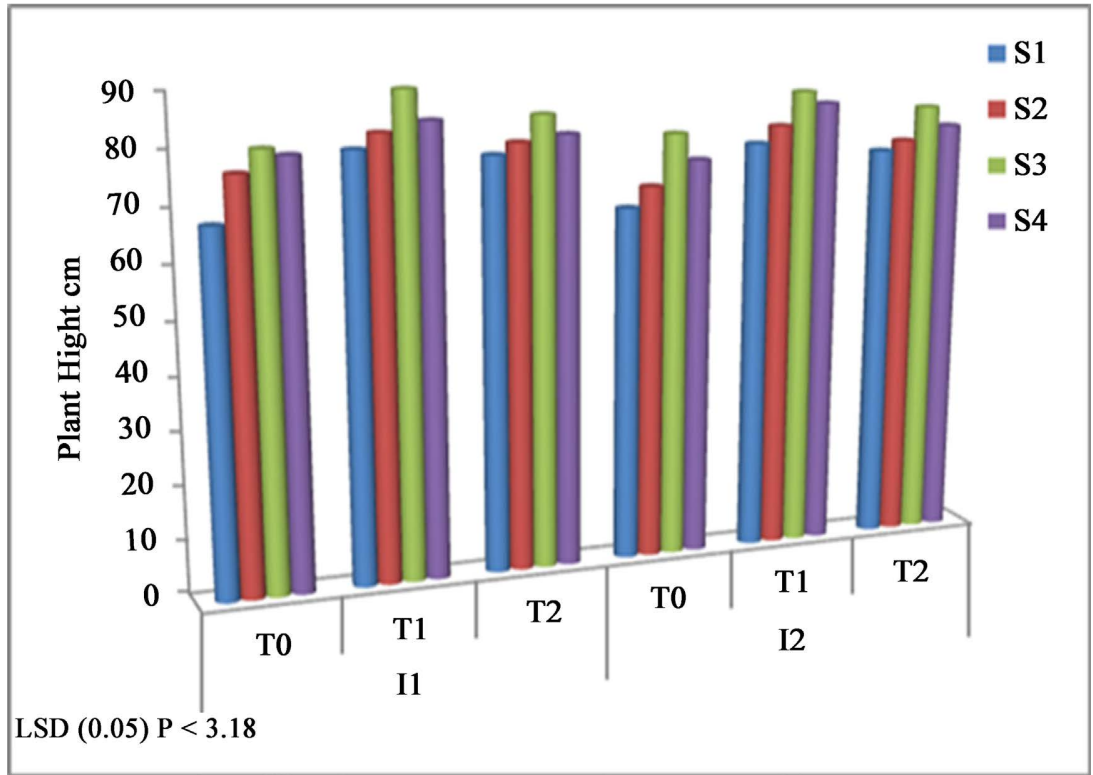

Figure 5. Effect of irrigation system tillage system and seeding rate on plant height $(\mathrm{cm})$ 2017-2018 season.

growing seasons where the high seeding rate S3 recorded the highest plant height 87.33 and $85.66 \mathrm{~cm}$ under minimum tillage T1 compared with the lowest average 66.83 and $67.16 \mathrm{~cm}$ under the influence of $\mathrm{S} 1$ and T0. For triple interaction, again, plants resulted from high seeding rate $\mathrm{S} 3$ under the minimum tillage T1 with sprinkler irrigation I1 gave the highest average of plant height 89.33 and $87.33 \mathrm{~cm}$ compared with the lowest ones 66.00 and $67.00 \mathrm{~cm}$ under the effect of the lowest seeding rate S1 zero tillage T0 and surface irrigation I2 in both growing seasons, respectively. Previous results clearly showed the importance of seeding rate $\mathrm{S} 3$ and tillage system $\mathrm{T} 1$ in giving the highest plant height under sprinkler irrigation I1. This suggests that resulted in plants can efficiently exploit the available growth resources supplied by tillage and irrigation. Many previous studies had dealt with the effect of seeding rate, e.g. [25] [15], on different wheat cultivars as a single factor. Combining the seeding rate with other factors as it was in this study may be a good approach to understanding the role of the seeding rate.

\subsubsection{Flag Leaf Area $\left(\mathrm{cm}^{2}\right)$}

Figure 6 and Figure 7 show the effect of study factors on the flag leaf area. It is clear that all factors and their interactions significantly affected this characteristic in both growing seasons. Concerning the irrigation system, sprinkler irrigation gave the highest average of 37.87 and $36.84 \mathrm{~cm}^{2}$ compared with 33.92 and $33.39 \mathrm{~cm}^{2}$ for surface irrigation in both growing seasons. This may be because sprinkler irrigation supplies plant vegetative growth with uniform and even quantities of water (i.e., uniform distribution), which makes water readily available for leaf growth, which, in turn, helps in cell division and expansion of flag leaf. Similar findings were obtained by [1], where a significant increase in the 


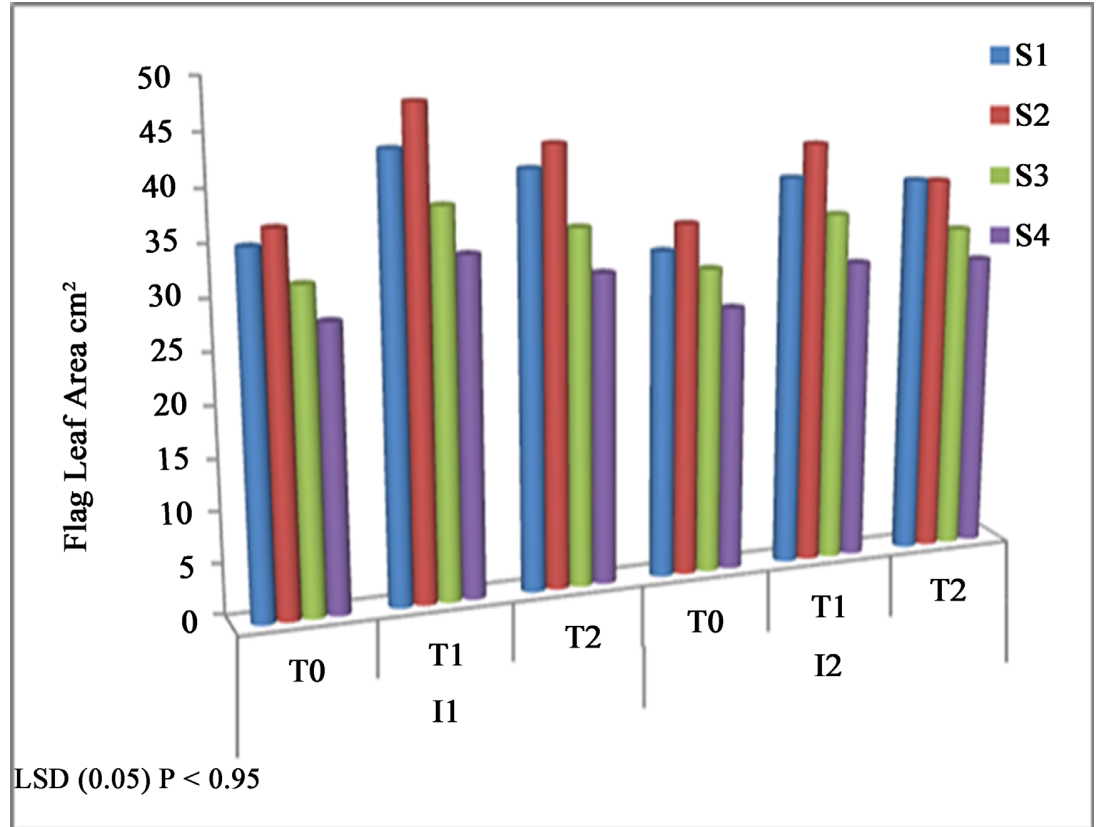

Figure 6. Effect of the irrigation system, tillage system, and seeding rate on flag leaf area $\left(\mathrm{cm}^{2}\right)$ 2016-2017 season.

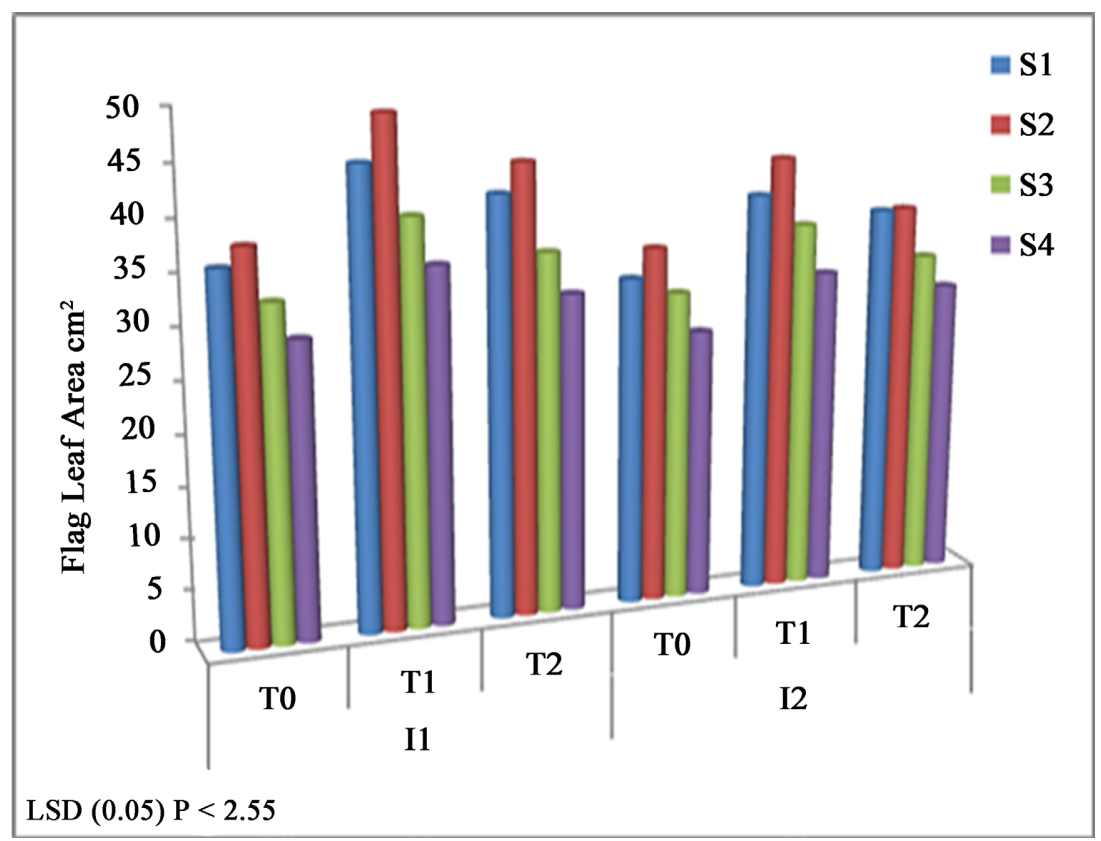

Figure 7. Effect of the irrigation system, tillage system, and seeding rate on Flag leaf area $\left(\mathrm{cm}^{2}\right)$ 2017-2018 season.

leaf area of wheat under the effect of sprinkler irrigation occurred. For the tillage system, minimum tillage (T1) recorded the highest average flag leaf area 39.60 and $38.10 \mathrm{~cm}^{2}$ compared with the lowest values 32.37 and $31.78 \mathrm{~cm}^{2}$ for zero tillage (T0) in both growing seasons, respectively. However, [25] found that zero tillage gave the highest average flag leaf area of durum wheat compared with the conventional tillage. Concerning seeding rate, the S2 $\left(180 \mathrm{~kg} \cdot \mathrm{ha}^{-1}\right)$ rate gave the 
highest value of the flag leaf area in both growing seasons $\left(40.84\right.$ and $\left.39.95 \mathrm{~cm}^{2}\right)$ compared with the $S 4\left(300 \mathrm{~kg} \cdot \mathrm{ha}^{-1}\right)$, which gave the lowest values $(30.20$ and $29.31 \mathrm{~cm}^{2}$ ) in both growing seasons, respectively. This result may be because high seeding rates produce dense plants, which, in turn, have small flag leaves. This result was in agreement with the findings of where the high seeding rate $\left(168 \mathrm{~kg} \cdot \mathrm{ha}^{-1}\right)$ gave the highest value of flag leaf area for durum wheat grown in the rainfed area of Iraq compared with the seeding rate $140 \mathrm{~kg} \cdot \mathrm{ha}^{-1}$ [24].

Figure 6 and Figure 7 also show that all interactions were significant. Concerning the interaction between the irrigation system and seeding rate, sprinkler irrigation recorded the highest average 43.56 and $42.34 \mathrm{~cm}^{2}$ at S2 seeding rate $\left(180 \mathrm{~kg} \cdot \mathrm{ha}^{-1}\right)$ compared with the lowest values 28.76 and $28.09 \mathrm{~cm}^{2}$ for surface irrigation and the highest seeding rate $\left(300 \mathrm{~kg} \cdot \mathrm{ha}^{-1}\right)$ in both growing seasons respectively. Minimum tillage (T1) with S2 seeding rate $\left(180 \mathrm{~kg} \cdot \mathrm{ha}^{-1}\right)$ gave the highest values of the flag leaf area (45.81 and $\left.44.32 \mathrm{~cm}^{2}\right)$ compared with (27.67 and $\left.27 \mathrm{~cm}^{2}\right)$ for zero-tillage and the highest seeding rate $\left(300 \mathrm{~kg} \cdot \mathrm{ha}^{-1}\right)$ in both growing seasons 2016-2017 and 2017-2018, respectively. For the triple interaction, sprinkler irrigation (I1) under the minimum tillage (T1) with the S2 seeding rate $\left(180 \mathrm{~kg} \cdot \mathrm{ha}^{-1}\right)$ recorded the highest average of flag leaf area (49.03 and $47.37 \mathrm{~cm}_{2}$ ) compared with the lowest values (26.37 and $26.03 \mathrm{~cm}_{2}$ ) obtained under the surface irrigation (I2), zero tillage (T0) and the highest seeding rate (300 $\mathrm{kg} \cdot \mathrm{ha}^{-1}$ ) in both growing seasons, respectively. This means that sprinkler irrigation was in favor of plant growth with the help of seeding rate (medium one) under minimum tillage [26] [27]. The response of the flag leaf area under the influence of interaction was better than the response to each factor as single.

\subsection{Grain Yield and Its Components}

\subsection{1. (Number of Grains) Spikes-1}

The number of grains per spikes is one of the important grain yield components, which is highly influenced by the environmental conditions and crop management. However, it is highly under genetic control [28]. Figures 8-11 represent the effect of study factors and their interactions on this characteristic in both growing seasons. Sprinkler irrigation, although an increased number of grains spikes-1, this increase was not significant in both growing seasons. The same trend was obtained for the number of spikes m-2 Figure 7 and Figure 8 as sprinkler irrigation recorded a non-significant increase over surface irrigation in both growing seasons. For the tillage system, minimum tillage (T1) significantly increased the number of grains pikes-1 (43.40 and 42.07) vs. (37.00 and 34.69) for zero tillage in both growing seasons, respectively. Seeding rates (S2 and S3) tended to give the highest number of grains spikes-1 with no significant differences between them compared with (39.23 and 35.06) for S4 seeding rate in both growing seasons, respectively.

This result was in accordance with the results of Figure 7 and Figure 8. The interaction between the irrigation system and the seeding rate was significant. Sprinkler irrigation (I1) with the S3 seeding rate gave the highest values (44.06 


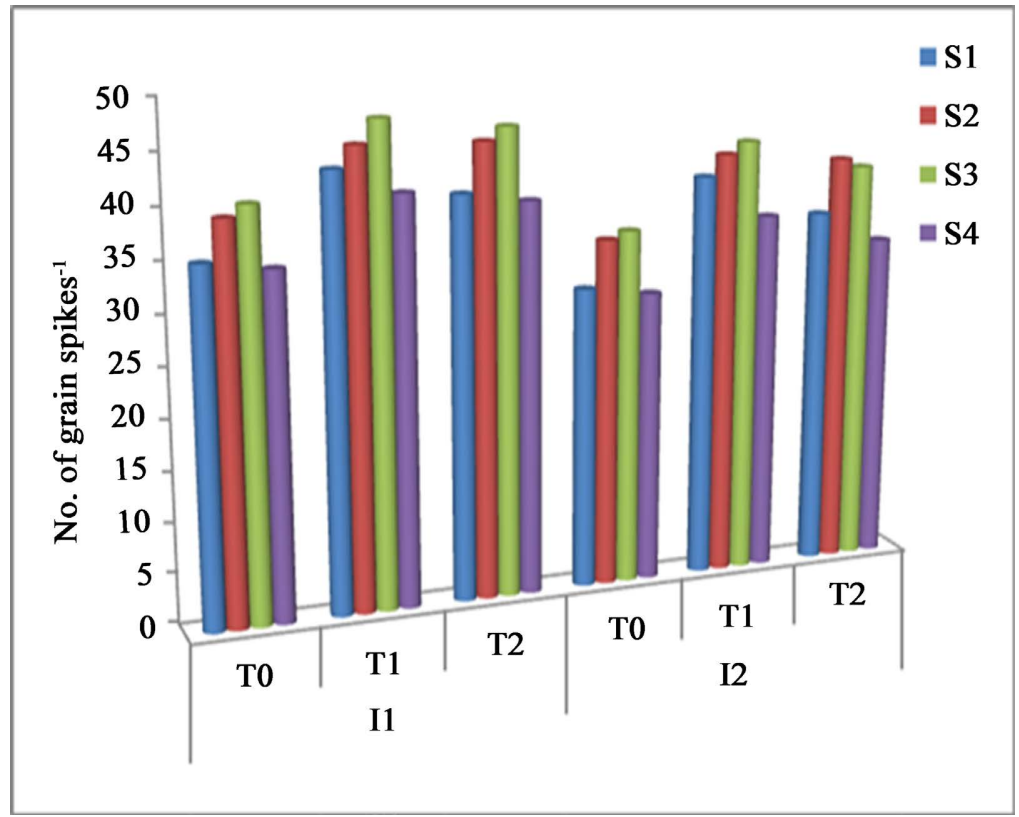

Figure 8. Effect of the irrigation system, tillage system, and seeding rate on the (number of grains) spikes-1 2016-2017 season.

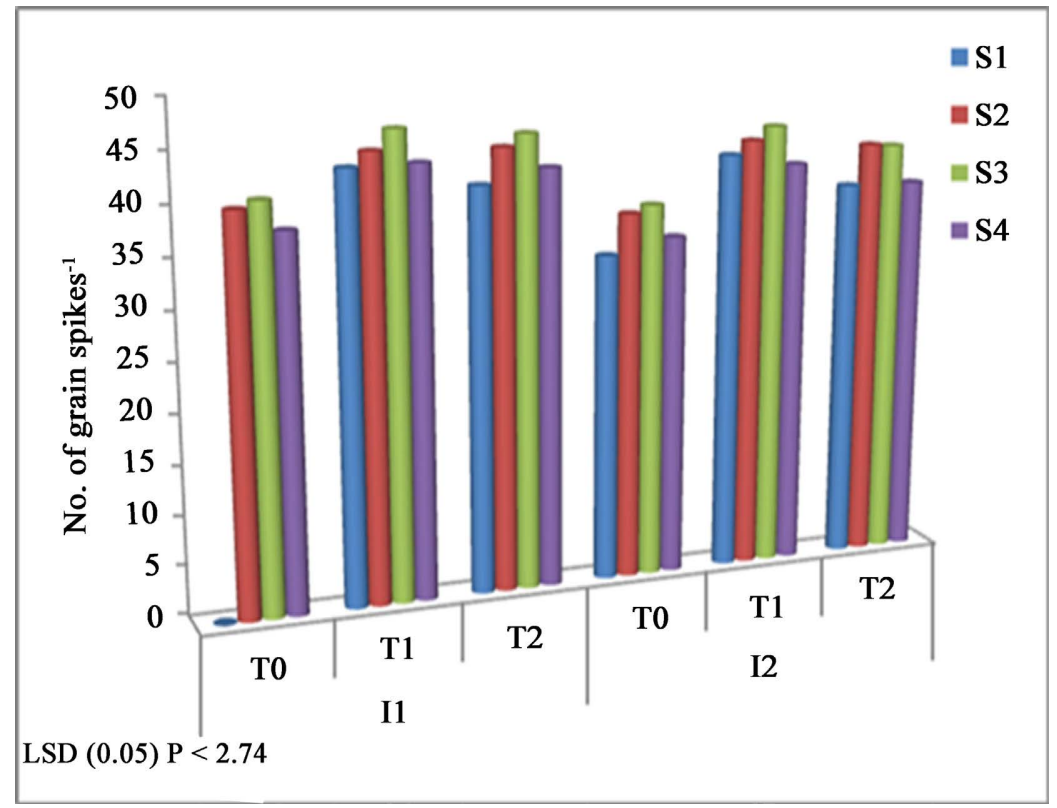

Figure 9. Effect of the irrigation system, tillage system, and seeding rate on the (number of grains) spikes-1 2017-2018 season.

and 44.6) grains spike-1 compared with the lowest one (37.63 and 32.2) for surface irrigation and the highest seeding rate (S4) in both growing seasons, respectively. Again, minimum tillage treatment (T1) recorded the highest average (45.45 and 45.26) grains spikes-1 under the S3 seeding rate compared with (35.90 and 31.57) for the zero tillage treatment and highest seeding rate (S4). The triple interaction was significant where sprinkler irrigation, minimum tillage, and seeding rate (S3) gave the highest values (46.4 and 47.4) compared with (34.23 and 


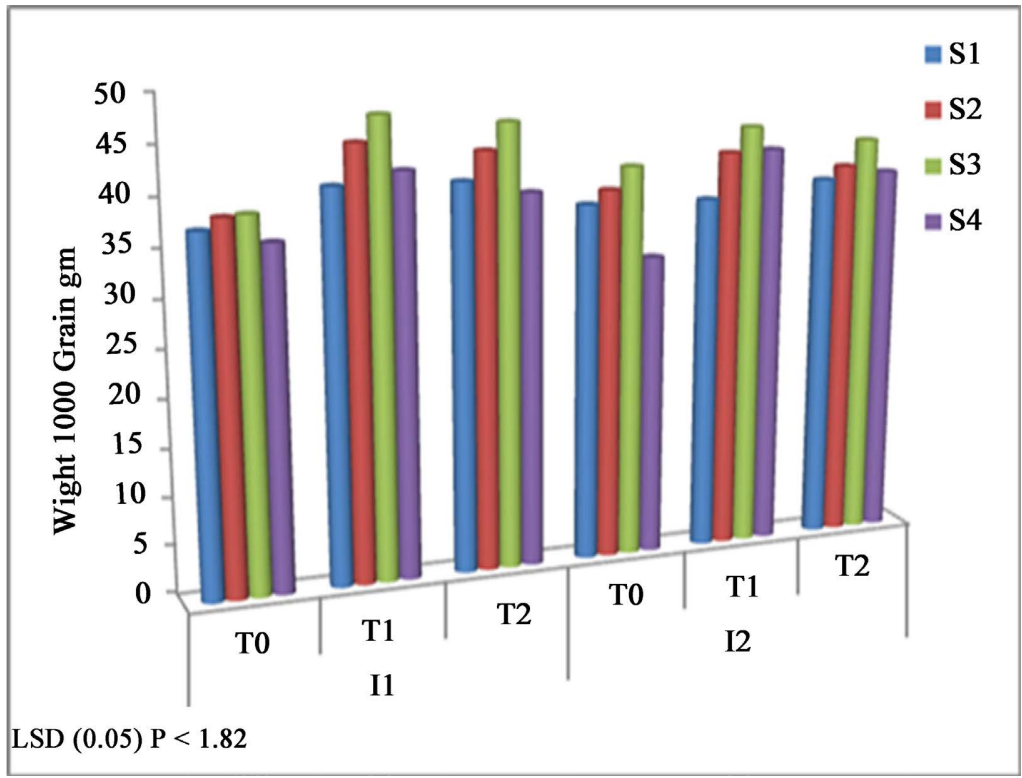

Figure 10. Effect of the irrigation system, tillage system, and seeding rate on 1000 grains weight 2016-2017 season

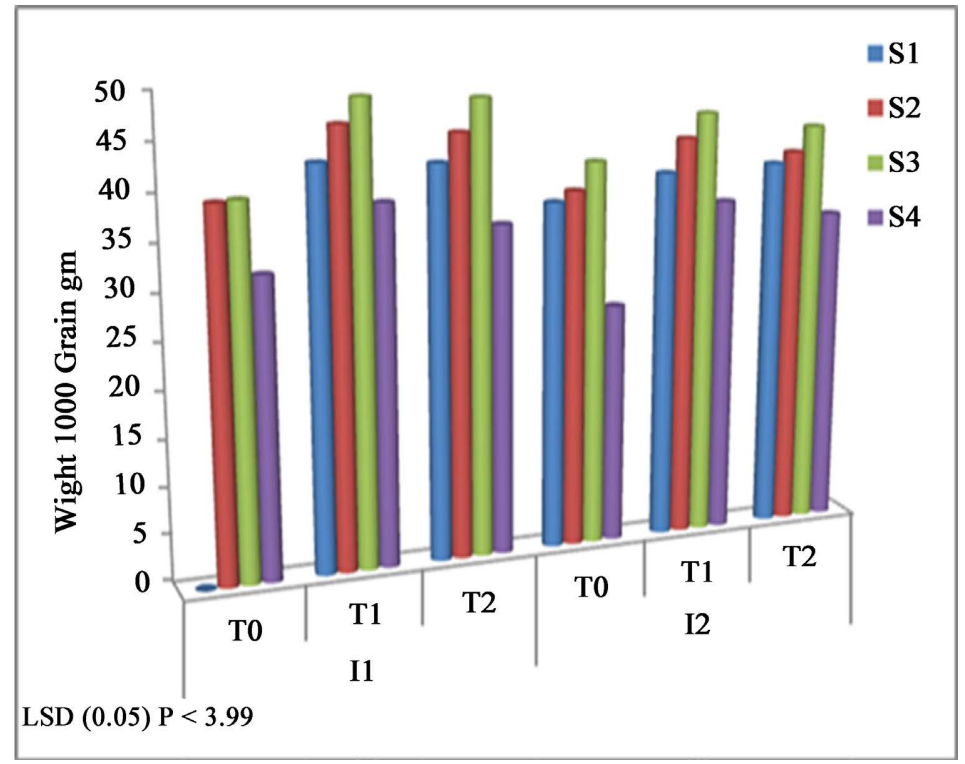

Figure 11. Effect of the irrigation system, tillage system, and seeding rate on 1000 grains weight 2017-2018 season.

28.9) grains spike-1 for surface irrigation, zero tillage, and (S4) seeding rate in both growing seasons, respectively.

\subsubsection{0-Grain Weight}

Grain weight is considered one of the major yield components in wheat. The final weight of grain depends upon the source strength in exporting photoassimilates, sink capacity, grain filling, and rate and period of filling of photoassimilates from the beginning of flowering until physiological maturity. Figure 12 and Figure 13 indicate the effect of study factors and their interactions on 1000- 
grain weight. Sprinkler irrigation significantly increased this characteristic in both growing seasons, recording the highest values (40.99 and 41.12) in both growing seasons compared with (38.34 and 39.05) g for surface irrigation, respectively. This may be due to the high values of the flag leaf area caused by sprinkler irrigation [29], Figure 6 and Figure 7. The flag leaf area is playing a vital role in supplying the developing grains with photoassimilates in the last growth stages (i.e., during the grain filling stage) as it supplies almost $80 \%$ of assimilates transported to developing grains due to their close position to the spikes [15]. Minimum tillage treatment (T1) increased this characteristic in both growing seasons (42.29 and $42.24 \mathrm{~g}$ ) compared with (36.3 and $37.12 \mathrm{~g}$ ) for zero tillage treatment, respectively.

However, [25] found no significant differences between zero tillage and conventional one in this characteristic. There was a significant gradual increase in the 1000-grain weight for the seeding rate with an increased seeding rate up to the highest seeding rate (S4), where a significant decrease occurred in Figure 11 and Figure 12. This decline in this characteristic may be due to reduced flag leaf area at the (S4) seeding rate (Figure 5 and Figure 6). The findings of [15] support this result where increased seeding rates decreased 1000-grain weight. Figure 11 and Figure 12 also indicate that all interactions were significant. Sprinkler irrigation (I1) at the seeding rate (S3) gave the highest average (45.44 and 43.44) g compared with (31.57 and 37.05) g for surface irrigation (I2) at the highest seeding rate (S4) in both growing seasons, respectively. For the tillage system, minimum tillage (T1) at the seeding rate $(\mathrm{S} 3)$ recorded the highest value of 1000-grain weight (46.95 and 45.6) g compared with (28.70 and 33.14) gm for zero tillage (T0) at the highest seeding rate (S4) in both growing seasons, respectively. Triple interaction shows that sprinkler irrigation (I1) with the minimum tillage (T1) under the seeding rate (S3) gave the highest value (48.8 and 47.27) gm compared with the lowest values (25.5 and 31.23) gm for surface irrigation (I2) with zero tillage (T0) at the highest seeding rate (S4) in both growing seasons, respectively. This means that the sprinkler irrigation favored this characteristic with the assistance of seeding rate (medium one) under the minimum tillage; that is, the response of 1000-grain weight under the influence of this interaction was better than the response to every single factor alone.

\subsubsection{Grain Yield $\left(\mathrm{t} \cdot \mathrm{ha}^{-1}\right)$}

Figure 12 and Figure 13 show the effect of the study factors (irrigation, tillage, and seeding rate) on the grain yield $\left(\mathrm{t} \cdot \mathrm{ha}^{-1}\right)$ and their interactions in both growing seasons. The sprinkler irrigation (I1) recorded the highest averages (4.32 and $\left.4.16 \mathrm{t} \cdot \mathrm{ha}^{-1}\right)$ compared with the lowest $\left(3.83\right.$ and $3.76 \mathrm{t} \cdot \mathrm{ha}^{-1}$ ) for surface irrigation (I2). This result may be due to the highest average flag leaf area [30]. Figure 6 and Figure 7 the (number of spikes) m-2. Figure 8 and Figure 9 also see 1000-grain weight (Figure 10 and Figure 11). Concerning the tillage system, minimum tillage (T1) in both growing seasons recorded the highest values (4.27 and 4.15 $\mathrm{t} \cdot \mathrm{ha}^{-1}$ ) compared with the lowest averages $\left(3.82\right.$ and $3.71 \mathrm{t} \cdot \mathrm{ha}^{-1}$ ) for zero tillage 


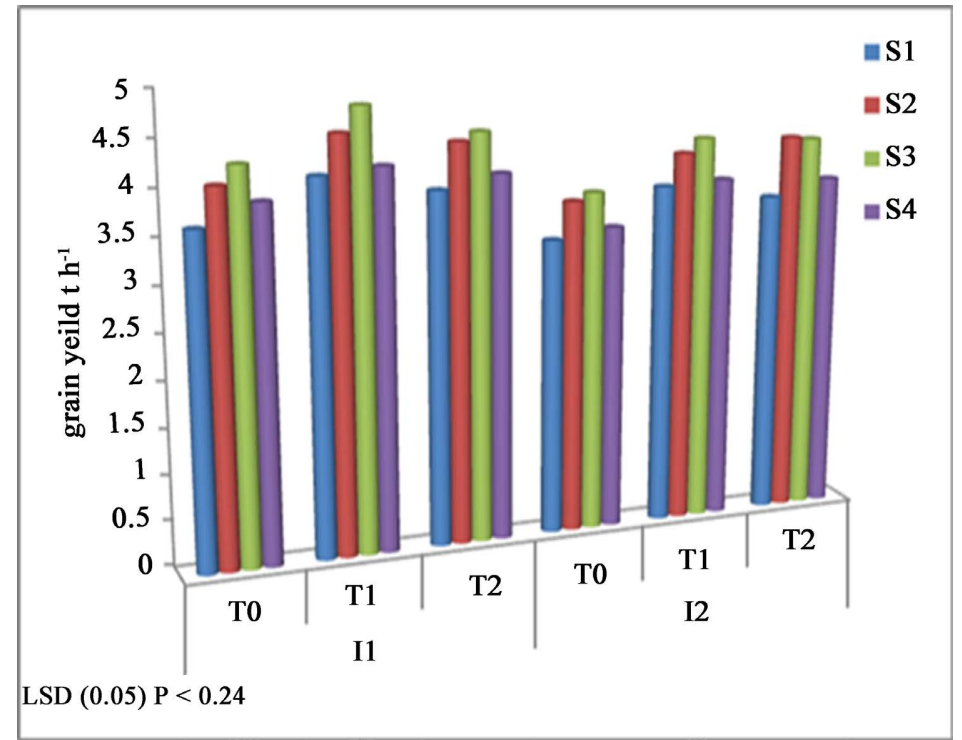

Figure 12. Effect of the irrigation system, tillage system, and seeding rate on grain yield $\left(\mathrm{t} \cdot \mathrm{ha}^{-1}\right)$ 2016-2017 season.

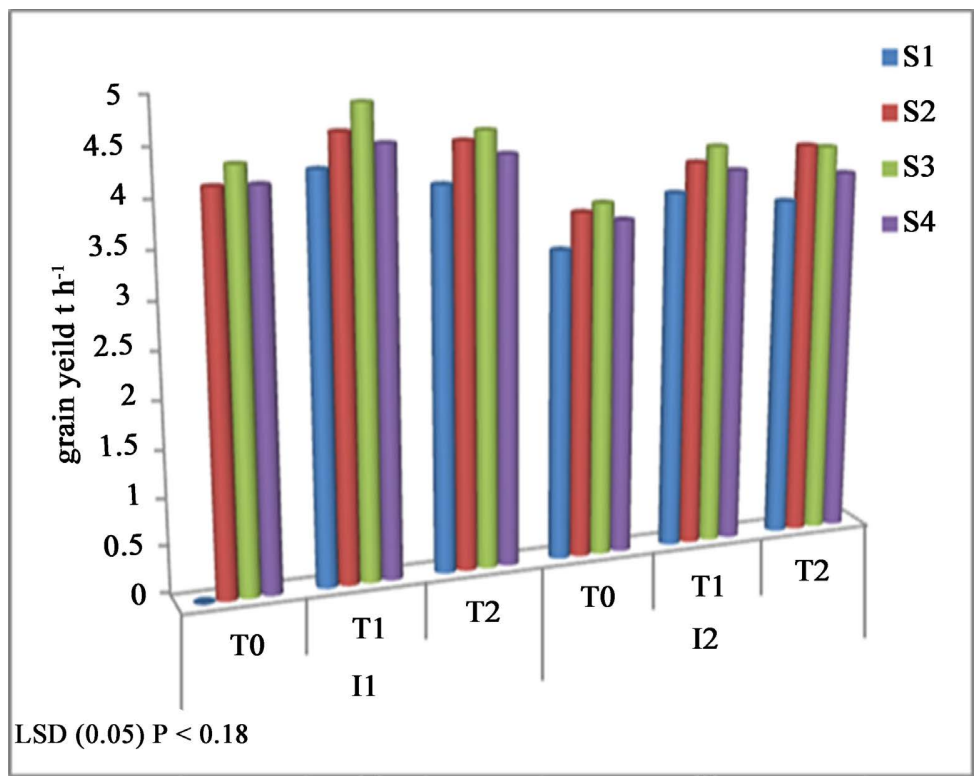

Figure 13. Effect of the irrigation system, tillage system, and seeding rate on grain yield $\left(\mathrm{t} \cdot \mathrm{ha}^{-1}\right)$ 2017-2018 season.

(T0), respectively. This result was due to the increase of the flag leaf area (Figure 4 and Figure 5), a (number of spikes) m-2 (Figure 6 and Figure 7), the number of grain spikes-1 (Figure 8 and Figure 9), and an increase 1000-grain weight (g) (Figure 10 and Figure 11) caused by the minimum tillage treatment.

For the seeding rate, there was a gradual increase in the grain yield with an increased seeding rate up to the S3 rate and then a decline at the S4 seeding rate in both growing seasons. This result was an outcome of the increased grain yield components: number of spikes/m-2 (Figure 6 and Figure 7), number of grains spikes-1 (Figure 8 and Figure 9), and 1000-grain weight (Figure 10 and Figure 
11). The present findings were in agreement with the results reported in [31] in wheat, where a similar trend was obtained. All interactions were significant. Sprinkler irrigation (I1) in both growing seasons at the seeding rate S3 gave the highest grain yield (4.58 and $4.48 \mathrm{t} \cdot \mathrm{ha}^{-1}$ ) compared with the lowest values $(3.54$ and $3.49 \mathrm{t} \cdot \mathrm{ha}^{-1}$ ) for surface irrigation (I2) at the lowest seeding rate (S1) respectively. Minimum tillage (T1) at seeding rate (S3) gave the highest values (4.54 and $\left.4.49 \mathrm{t} \cdot \mathrm{ha}^{-1}\right)$ in both growing seasons compared with the lowest values $(3.52$ and $343 \mathrm{t} \cdot \mathrm{ha}^{-1}$ ) for zero tillage and seeding rate (S1). In triple interaction, the highest grain yield (4.87 and $4.77 \mathrm{t} \cdot \mathrm{ha}^{-1}$ ) was obtained under the influence of sprinkler irrigation (I1), minimum tillage (T1), and (S3) seeding rate in both growing seasons compared with the lowest values (3.27 and $3.23 \mathrm{t} \cdot \mathrm{ha}^{-1}$ ) under the influence of surface irrigation (I2), zero tillage (T0) and lowest seeding rate (S1).

\subsection{Water Consumptive Use}

Figure 14 and Figure 15 refer to the water balance equation factors for the different irrigation treatments of wheat represented by ETa. It was noted that there were significant differences in the actual ETa values of wheat under different irrigation treatments. The highest water consumptive use of wheat was at the surface irrigation (557.5 and $535.9 \mathrm{~mm}$ season-1) compared with (460.9 and 442.6 $\mathrm{mm}$ season-1) for sprinkler irrigation in both growing seasons 2016-2017 and 2017-2018, respectively. This may be due to the increased number of irrigations 13 and 14 in both growing seasons for the surface irrigation treatment (Figure 15). However, the irrigation number under the sprinkler irrigation was 16 and 17 in both growing seasons, Figure 14. The differences in the consumptive water use in both irrigation systems may be attributed to the increased added water quantities at each time due to the decreased irrigation efficiency for surface irrigation compared with sprinkler irrigation. This explanation was supported by the findings reported in [32] [33]. Moreover, the reason for increased water

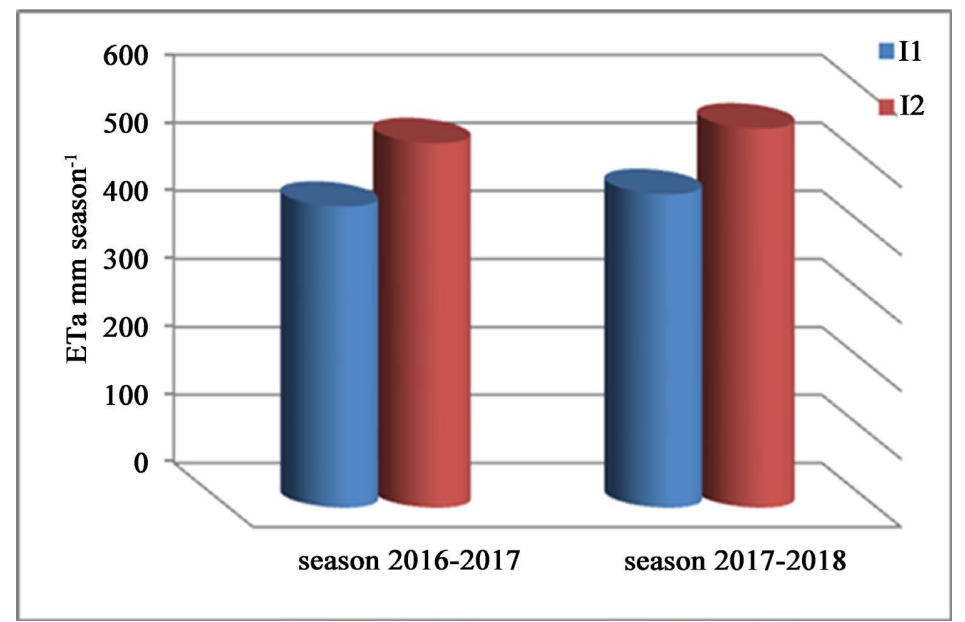

Figure 14. Effect of the irrigation system, tillage system, and seeding rate on ETa for 2016-2017 and 2017-2018 seasons. 
consumption for surface irrigation may be due to the availability of moisture content for plants at depths makes water available for them which, in turn, increases the plant water consumption where paints stomata are widely opened with high loses of water via transpiration [34] [35].

\subsection{Field Water Use Efficiency}

Figure 16 and Figure 17 represent the effect of the irrigation system, tillage system, seeding rate, and their interactions on the field water use efficiency (WUE) in both growing seasons. The average WUE were $(1.10$ and 0.82$) \mathrm{kg} \cdot \mathrm{m}^{-3}$ and (1.06 and 0.78$) \mathrm{kg} \cdot \mathrm{m}^{-3}$ for sprinkler and surface irrigation in both growing seasons,

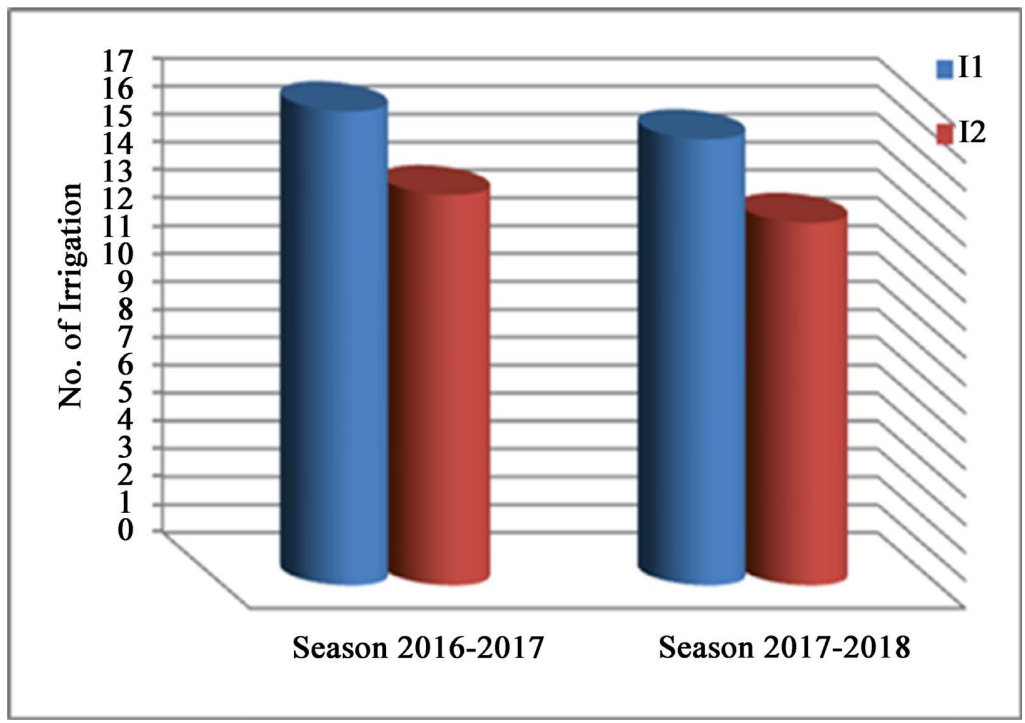

Figure 15. Effect of irrigation system tillage system and seeding rate on No. of irrigation for 2016-2017 and 2017-2018 seasons.

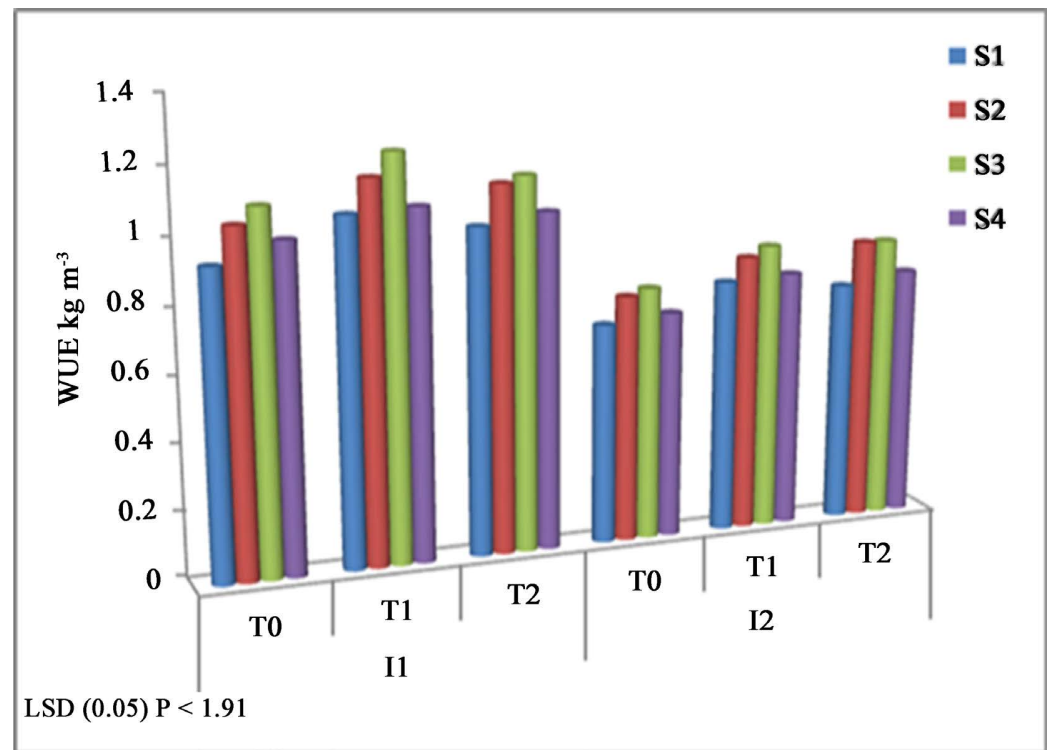

Figure 16. Effect of irrigation system tillage system and seeding rate on waiter use efficiency $\left(\mathrm{kg} \cdot \mathrm{m}^{-3}\right)$ 2016-2017 season. 


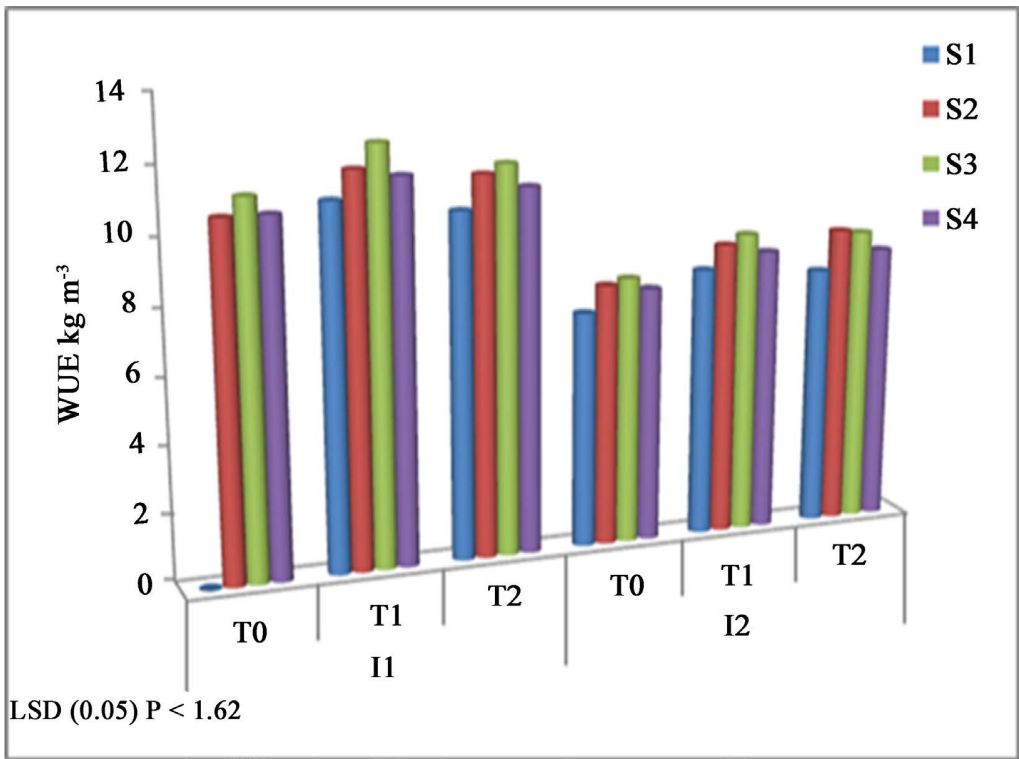

Figure 17. Effect of irrigation system tillage system and seeding rate on waiter use efficiency $\left(\mathrm{kg} \cdot \mathrm{m}^{-3}\right)$ 2017-2018 season.

respectively. for tillage system the values of WUE were $(0.09,1.01$ and 0.97$)$ and $(0.87,0.97$, and 0.93$) \mathrm{kg} \cdot \mathrm{m}^{-3}$ in both growing seasons 2016-2017 and 2017-2018 respectively. Concerning the seeding rate, the values of WUE were $(0.89,0.98$, 1.02 and 0.95$) \mathrm{kg} \cdot \mathrm{m}^{-3}$ and $(0.99,0.96,0.86$ and 0.88$)$ for (S3, S2, S1, and S4) in both growing seasons. The reason for increasing WUE in sprinkler irrigation (I1) was due to the decrease in water consumption, as in Figure13, compared with surface irrigation (I2); this result was supported by the finding of [36] [37]. The reduced WUE under the effect of zero tillage (T0) may be due to the decrease grain yield for this treatment, according to Figure 12 and Figure 13, compared with (T1) and (T2) treatments with an increase of 10.89 and $7.2 \%$, respectively, over to treatment, a similar result was found by [38] [39]. The differences between seeding rates were not significant for triple interaction. The highest values (1.24 and $\left.1.22 \mathrm{~kg} \cdot \mathrm{m}^{-3}\right)$ were at (I1T1S3) were compared with the lowest values $\left(0.71\right.$ and $0.67 \mathrm{~kg} \cdot \mathrm{m}^{-3}$ ) at (I2T0S1) in both growing seasons 2016-2017, and 2017-2018. This may be because sprinkler irrigation gave the highest uniformity of water distribution and less water consumption. Besides, that minimum tillage (T1) gave the best root distribution, improving the growth characteristics. Also, the seeding rate of $240 \mathrm{~kg} \cdot \mathrm{ha}^{-1}$ (S3) gave the highest grain yield, described in Figure 11 and Figure 12, this result was in agreement with the findings of [40] [41] [42] [43].

\section{Conclusion}

The present study's findings highlighted the important role of the sprinkler irrigation system in the improvement of the growth attributes under the minimum tillage system and the suitable seeding rate. This synergistic action of these factors increased grain yield and its components. Furthermore, wheat production 
costs might be reduced considerably following sprinkler irrigation and minimum tillage systems with saving water via less water consumption and high water use efficiency.

\section{Conflicts of Interest}

The authors declare no conflicts of interest regarding the publication of this paper.

\section{References}

[1] Rathore, V.S., Narayam, S.N., Seema, B., Renjih, P.S., Bhagirath, M.Y., Mahesh, K., Priyabrata, S., Narendra, D.Y. and Om Parkash, Y. (2017) Yield Water and Nitrogen Use Efficiencies of Sprinkler Irrigated Wheat Grown under Different Irrigation and Nitrogen Levels in an Arid Region. Agricultural Water Management, 187, 232245. https://doi.org/10.1016/j.agwat.2017.03.031

[2] FAOSTAT (Food and Agriculture Organization Corporate Statistical Database) (2017) FAOSTAT Agricultural Data. https://www.fao.org/statistics/en/

[3] Chaves M.O. and Oliveira, M.M. (2004) Mechanisms Underlying Plant Resilience to Water Deficits Prospects for Water-Saving Agriculture. Journal of Experimental Botany, 55, 2365-2384. https://doi.org/10.1093/jxb/erh269

[4] Dhanda, S.S., Sethi, G.S. and Behl, R.K. (2004) Indices of Drought Tolerance in Wheat Genotypes at Early Stages of Plant Growth. Journal of Agronomy and Crop Science, 190, 6-12. https://doi.org/10.1111/j.1439-037X.2004.00592.X

[5] Stewart, B.A. and Howell, T.A. (2003) Drought Evidance and Drought Adaptation. In: Stewart, B.A. and Howell, T.A., Eds., Encyclopedia of Water Science, Vol. 1076, Marcel Dekker, New York, 163-169.

[6] Jassim, B.Sh. (2015) Wheat Seed Priming (Triticum aestivum L.) for Drought Tolerance. Ph.D. Thesis, College of Agriculture, University of Baghdad, Baghdad.

[7] Sojka, R.E., Bjorneberg, D.L. and Entry, J.A. (2002) Irrigation: An Historical Perspective. Soil Scientist, Irrigation Engineer, and Soil Microbiologist, Kimberly, Idaho, U.S.A. In: Lal, R., Ed., Encyclopaedia of Soil Science, Marcel Dekker, Inc., New York, 745-749.

[8] AL-Ghobari, H.M. and El Marazky, M.S. (2014) Effect of Smart Sprinkler Irrigation Utilization on Water Use efficiency for Wheat Crops in Arid Regions. International Journal of Agricultural and Biological Engineering, 7, 26-35.

[9] Reicosky, D.C. (1997) Tillage Induced $\mathrm{Co}_{2}$ Emissions from Soil. Nutrient Cycling in Agroecosystems, 49, 273-285. https://doi.org/10.1023/A:1009766510274

[10] Choudhary, M., Jat, H.S., Datta, A., Yadav, A.K., Mondal, T.B., Meena, R.P., Sharma, P.C. and Jat, M.L. (2018) Sustainable Intensification Influences Soil Quality, Biota, and Productivity in Cereal-Based Agro System. Applied Soil Ecology, 126, 189 198. https://doi.org/10.1016/j.apsoil.2018.02.027

[11] Guo, Y., Yin, W., Hu, F., Fan, Z., Fan, H., Zhao, C., Yu, A., Chaiand, Q. and Coulter, J. (2019) Reduced Irrigation and Nitrogen Coupled with No Tillage and Plastic Mulching Increase Wheat Yield in a Maize-Wheat Rotation in an Arid Region. Field Crop Research, 243, Article ID: 107615. https://doi.org/10.1016/j.fcr.2019.107615

[12] Kalhapure, A., Vijay, P.S., Rajeew, K. and Pandey, D.S. (2015) Tillage and Nutrient Management in Wheat with Different Plant Geometries under Rice-Wheat Cropping System: A Review. Basic Research Journal of Agricultural Science and Review, 
4, 296-303.

[13] AL-Dulaimi, A.A.Kh. (2016) Effect Tillage System and Levels of Phosphate Fertilizer on the Optical Properties for Wheat Yield (Triticum aestivum L.) in Gypsiferous Soil. Tikrit Journal for Agricultural Sciences, 16, 1-13.

[14] Honsdorf, N., Verhulst, N., Crossa, J., Vargas, M., Govaerts, B. and Ammar, K. (2019) Durum Wheat Selection under Zero Tillage Increases Early Vigor and Is Neutral to Yield. Field Crop Research, 248, Article ID: 107675. https://doi.org/10.1016/j.fcr.2019.107675

[15] Al Hassan, M.F.H. (2011) Understanding of Tillering in Different Wheat Cultivars as Influenced by Seeding Rate and Nitrogen Levels and Its Relationship to Grain Yield and Its Components. PH.D. Thesis, College of Agriculture University of Baghdad, Baghdad.

[16] Abd Al-Redhia, J.J. (2002) Evaluate the Performance of the Semi-Constant Sprinkler Irrigation System and Its Effect on Soil Moisture Distribution and Livestock Yield. Master Thesis, Faculty of Agriculture, University of Baghdad, Baghdad.

[17] Payne, R.W. (2009) GenStat. WIREs Computational Statistics, 1, 255-258. https://doi.org/10.1002/wics.32

[18] Jaddoa, K. and Salih, H.M. (2013) Fertilization of Wheat Crop. Extension Leaflet No. 2, Ministry of Agriculture, Republic of Iraq.

[19] Kovda, V.A., Vande Berg, C. and Hangun, R.M. (1973) Irrigation, Drainage and Salinity. Food and Agriculture Organization, United Nations Educational, Scientific and Cultural Organization, London.

[20] Allen, R.G., Pereira, L.S., Raes, D. and Smith, M. (1998) Crop Evapotranspiration. FAO Irrigation and Drainage. Paper No. 65, Food and Agriculture Organization of United Nations, Rome.

[21] Robertson, M.J. and Giunta, F. (1994) Responses of Spring Wheat Exposed to PreAnthesis Water Stress. Australian Journal of Agricultural Research, 45, 19-35. https://doi.org/10.1071/AR9940019

[22] A.O.A.C. (Association of Official Analytical Chemists) (1975) Official Methods of Analysis. Association of Official Analytical Chemists, Washington DC.

[23] Shahzad, K., Bakht, J., Shah, W.A., Shafi, M. and Jabeen, N. (2002) Yield and Yield Components of Various Wheat Cultivars as Affected by Different Sowing Dates. Asian Journal of Plant Sciences, 1, 522-525. https://doi.org/10.3923/ajps.2002.522.525

[24] Mahmoud, H.H.H. (2007) Effect of Specific Weight, Seeding Rate, Fertilizer, and Tillage System on Growth, Grain Yield, and Its Component of Durum Wheat (Triticum durum Desf). M. Sc. Thesis, University of Mosul, Mosul.

[25] Sezen S.M. and Yazar A. (2006) Wheat Yield Response to Line-Source Sprinkler Irrigation in the Arid Southeast Anatolia Region of Turkey. Agricultural Water Management, 81, 59-76. https://doi.org/10.1016/j.agwat.2005.04.011

[26] Zotarelli, L., Scholberg, J.M., Dukes, M.D., Muñoz-Carpena, R. and Icerman, J. (2009) Wheat Yield, Biomass Accumulation, Root Distribution, and Irrigation Water Use Efficiency on Sandy Soil, as Affected by Nitrogen Rate and Irrigation Scheduling. Agricultural Water Management, 961, 23-34. https://doi.org/10.1016/j.agwat.2008.06.007

[27] Xue, Q.A., Baenziger, W.P.S. and Shelton. D.R. (2011) Seeding Rate and Genotype Affect Yield and End-Use Quality in Winter Wheat. Journal of AcroCrop Science, 2, 18-25

[28] Gontia, N.K. and Tiwari, K.N. (2008) Development of Crop Water Stress Index of 
the Wheat Crop for Scheduling Irrigation Using Infrared Thermometry. Agricultural Water Management, 95, 1144-1152.

https://doi.org/10.1016/j.agwat.2008.04.017

[29] Bijanzadeh, E. and Emam, Y. (2012) Evaluation of Crop Water Stress Index, Canopy Temperature, and Grain Yield of Five Iranian Wheat Cultivars under Late-Season Drought Stress. Journal of Plant Physiology and Breeding, 2, 23-33.

[30] Ayed, S., Rezgui, M., Othmani, A., Rezgui, M., Trad, H., Teixeira-da Silva, J.A., Ben Younes, M., Ben Salah, H. and Kharrat, M. (2017) The Response of Tunisian Durum (Triticum turgidum ssp. durum) and Bread (Triticum aestivum L.) Wheats to Water Stress. Agrociencia, 51, 13-26.

[31] Liu, H.J. and Kang, Y. (2006) Effect of Sprinkler Irrigation on Microclimate in the Winter Wheat Field in the North China Plain. Agricultural Water Management, 84, 3-19. https://doi.org/10.1016/j.agwat.2006.01.015

[32] Sun, H.Y., Shen, Y., Yu, Q., Flerchinger, G.N., Zhang, Y., Liu, C. and Zhang, X. (2009) Effect of Precipitation Change on Water Balance and WU of the Winter WheatSummer Maize Rotation in the North China Plain. Agricultural Water Management, 97, 1139-1145. https://doi.org/10.1016/j.agwat.2009.06.004

[33] Zwain, H.M., Almurshedi, K.R., Vakili, M., Dahlan, I. and Naje, A.S. (2021) Water Quality and Radionuclides Content Assessment of AL-Najaf Sea: Case Study. Journal of Ecological Engineering, 22, 262-271. https://doi.org/10.12911/22998993/131183

[34] Kang, S. and Zhang, J. (2004) Controlled Alternate Partial Root-Zone Irrigation: Its Physiological Consequences and Impact on Water Use Efficiency. Journal of Experimental Botany, 55, 2437-2446. https://doi.org/10.1093/jxb/erh249

[35] Yonts, C.D., Lamm, F.R., Kranz, W. and Payero, J. (2005) Impact of Drop Spacing and Sprinkler Height for Corn Production. Proceedings of 2004 Central Plains Irrigation Conference, Kearney Nebraska, 17-18 February 2005, 110-115.

[36] Zapata, R.N., Playán, E., Martínez-Cob, A., Sánchez, I., Faci, J.M. and Lecina, S. (2007) From on-Farm Solid-Set Sprinkler Irrigation Design to Collective Irrigation Network Design in Windy Areas. Agricultural Water Management, 87, 187-199. https://doi.org/10.1016/j.agwat.2006.06.018

[37] Cantero-Martinez, C., Angas, P. and Lampurtanes, J. (2007) Long-Term Yield and Water Use Efficiency under Various Tillage Systems in Mediterranean Rainfed Conditions. Annals of Applied Biology, 150, 293-305. https://doi.org/10.1111/j.1744-7348.2007.00142.x

[38] Martinez, E., Fuentes, J.P., Silva, P., Valle, S. and Acevedo, E. (2008) Soil Physical Properties and Wheat Root Growth under No-Tillage and Conventional Tillage Systems in a Mediterranean of Chile. Soil and Tillage Research, 99, 232-244. https://doi.org/10.1016/j.still.2008.02.001

[39] Younis, A.F., Amin, Z.A. and Ra'ad, G.M. (2011) Effect of Different Tillage Systems on some Physical Properties of Soil and Barley Growth. Journal of Kirkuk University for Agricultural Sciences, 2, 1-9.

[40] Houria, C. and Saci, A. (2012) The Performances of Durum Wheat Yield (Triticum durum Desf.) under Tillage Effect in Semi-Arid Environment. Energy Procedia, 18, 879-887. https://doi.org/10.1016/j.egypro.2012.05.102

[41] Karrou, M. (2013) Combined Effect of Tillage System, Supplemental Irrigation, and Genotype on Bread Wheat Yield and Water Use in the Dry Mediterranean Region. African Journal of Agricultural Research, 8, 5398-5404. 
[42] Hassan, D.F., Jafaar, A.A. and Mohammad, R.J. (2019) Effect of Irrigation Water Salinity and Tillage Systems on Some Physical Soil Properties. Iraqi Journal of Agricultural Sciences, 50, 42-47. https://doi.org/10.36103/ijas.v50iSpecial.175

[43] Mohammed, R.J., Abdulkadhim, K.A., Hassan, D.F. and Kadhim, T.F. (2019) Effect of Wheat Straw as Organic Matter and Different Water Quality on Some Chemical Soil Properties and Growth of Pepper (Capsicum annuum). IOP Conference Series. Earth and Environmental Science, 344, Article ID: 012034.

https://doi.org/10.1088/1755-1315/344/1/012034 